\title{
Using the RME Principles to Support Students Problem Solving be HOTS Oriented
}

\author{
Sabina Ndiung \\ \{punyaku79@gmail.com\} \\ Universitas Katolik Indonesia Santu Paulus Ruteng ${ }^{1}$
}

\begin{abstract}
This study aims to explain the RME approach for improving elementary school students' problem-solving ability be HOTS Oriented. This analysis is an experimental study that employs a pretest-posttest control group design. The study sample consisted of 41 grade V SDK Wae Mata. The data testing technique employed a five-item test with a reliability coefficient of 0.83 in the high category. The data analysis technique used in this study was parametric statistical techniques with an independent t-test preceded by a test for data normality and variant homogeneity using the SPSS 23.0. This is indicated by the value of tobs $=38.071>$ from tcrv $=2.021$ with a significance of $0.001<0.05$. This result indicates that implementing the RME approach, as demonstrated by the RME principles, could support students to problem-solving ability be HOTS Oriented
\end{abstract}

Keywords: Mathematics, Problem-solving ability, RME principles

\section{Introduction}

Today's education must be oriented toward a twenty-first-century education, enabling educators to prepare students with the "four Cs," critical thinking and problem-solving communication and collaboration, and creativity and innovation. Educators need to prepare students with the "four Cs," or critical thinking and problem-solving communication and collaboration, and creativity and innovation. New standards are required to ensure that students possess the competencies needed to resolve the second theme, namely learning and innovation skills. These skills include (1) critical thinking and problem-solving, in which students can apply inductive or deductive reasoning to a variety of situations; use a systematic way of thinking; and make decisions and solve problems (2) communication and collaboration, where students can communicate clearly and collaborate with other group members; and (3) creativity and innovation, that students can think creatively, work creatively and create innovations [1], [2].

Improving education's quality can be accomplished by enhancing both the quality of learning and the quality of the assessment system. The basic concept of assessment developed refers to the latest revision in the 2013 Curriculum, which center on improvements to the content standards and assessment standards. The content standard is designed to develop students' ability to think critically and analytically following international standards, which is done by reducing irrelevant material and the enhancement and expansion of relevant material for students. In contrast, the assessment standard is implemented through the adaptation of international standard assessment models gradually. Assessment of learning outcomes focuses more on higher-order thinking skills [3]. 
The government expects students to achieve various competencies by implementing High Order Thinking Skills (HOTS). These competencies include critical thinking, creativity and innovation, communication and collaboration skills, and confidence. The five points conveyed by the government regarding the students' character of the target are embedded in our national exam evaluation system and constitute 21 st-century skills. HOTS is also implemented following the low ranking of the Program for International Student Assessment (PISA) and Trends in International Mathematics and Science Study (TIMSS) compared to other countries to increase the quality of national test questions.

Students' high-level thinking skills are carried out based on the Program for International Student Assessment (PISA) study, which shows that the achievement of reading literacy, mathematical literacy, and scientific literacy of Indonesian students is very low. Up to the present, several learning outcome instruments used by teachers for regular assessments and those used by schools for standardized assessments have not resulted in students' reasoning being challenged about the resolution of unusual problems that involve non-routine procedures [4]. As evidenced by the report on the results of the 2018 PISA survey, which included 79 countries, Indonesian students have an unsatisfactory ranking that tends to stagnate over the last 10-15 years. The study results show that literacy is ranked 72 nd out of 77 countries, Mathematics is ranked 72 nd out of 78 countries, and Science is ranked 70th out of 78 countries, which makes Indonesia ranked in the 74th [5]. Higher-order thinking skills can be developed in the classroom through the mathematics learning process.

However, the application of learning-oriented towards the formation of higher-order thinking skills is not something that the teacher easily carries out. The teacher must comprehend the material and learning strategies, and the teacher is also faced with challenges with the students' environment. Learning will be meaningful if students are asked to think at a higher level. The success of mastering a concept will be obtained when students can think at high levels. To ensure students' HOTS develop correctly, students need to be familiarized with activities that train HOTS itself where students can remember and understand a concept and analyze and synthesize, evaluate, and create a concept effectively.

Since a concept that has been understood will keep embedded in their brain for an extended period, students need to possess higher-order thinking skills [6]. Higher-order thinking skills involve analysis and synthesis (C4), evaluating (C5), and creating or creativity (C6). HOTS is very important to be applied and developed in classroom learning. In this case, if students have high-order thinking skills, they are capable of effectively solving math problems [7]. It is necessary to have an appropriate strategy in teaching mathematics in elementary school.

Thus, learning becomes meaningful and enjoyable when the teacher successfully presents it into a teaching process that challenges students' thinking. The Realistic Mathematics Education (RME) approach is one approach for addressing the issue of creating higher-order thinking processes. Assuming that mathematics is an abstract science and students' cognitive growth is still in the concrete operational thinking process. The RME approach is a learning concept where the teacher presents real-world situations into the classroom and encourages students to connect the knowledge they have and its application in life [8].

The concept of RME was first introduced by Freudenthal, who said that mathematics must be related to reality and mathematics is a human activity. This concept means that mathematics must be relevant to students' daily lives. This idea means that mathematics must be close to students' world and relevant to real-life every day. Mathematics as a human activity means that humans must be allowed to recreate mathematical ideas and concepts under adult guidance. RME is an approach to teaching mathematics that focuses on developing concepts through rediscovery based on participants' experiences and knowledge. In the context of this research, 
the steps used in mathematics learning employed RME principles which have been developed by Marja van den Heuvel-Panhuizen. Heuvel-Panhuizen reformulate six principles of RME: activity, reality, hierarchy, interconnection, interaction, and guidance principles [9].

The activity principle emphasizes the importance of students being active participants in the learning process; activities are mostly carried out by students and the reality principle suggests that learning activities become more connected to students' "real-life" issues. Moreover, the level principle underlines that learning mathematics means students should pass various levels of understanding: from informal context-related solutions, through creating various levels of shortcuts and schematizations to acquiring insight into how concepts and strategies are related.

Next, the intertwinement principle concerns the mathematical content domains such as number, geometry, measurement, and data handling are not viewed as isolated curriculum chapters but as heavily integrated. Students are offered lots of problems in which they can use their various mathematical tools and knowledge. Furthermore, the interactivity principle means that learning mathematics is not only an individual activity but also a social activity, and then the guidance principle refers to Freudenthal's idea of "guided re-invention" of mathematics [9], [10].

The use of RME in mathematics education has been extensively studied in a variety of educational studies. Research conducted by [11] shows that RME can increase students' mathematics learning activities where through real context learning students are able to construct their knowledge properly through teacher guidance. Similarly, his research [12] shows that the increase in learning outcomes and reasoning of students in learning mathematics using the RME approach is better than using the conventional approach. Additionally, research from [13] indicates that students who use the RME approach achieve higher mathematics learning outcomes than students who use conventional approaches. As is the case [14] their research findings indicate that using a realistic mathematics approach can increase students' activity and motivation, improve their mastery of mathematical concepts, foster student collaboration, foster a harmonious relationship between students and students, and students with teachers as well. Similarly, [15] demonstrates that RME can improve student engagement and learning outcomes.

By focusing on the success of RME in mathematics learning, teachers must also consider their student's cognitive growth to better apply the concepts of RME. Numerous studies have shown that the RME approach can help individuals develop their problem-solving skills. As shown by research conducted by [16]. RME learning has an impact on students' problem-solving skills. According to [17]), his research demonstrates that the Realistic Mathematics Education (RME) model is successful in helping elementary school fifth-grade students solve math problems.

Similarly, [18] demonstrates that the realistic mathematics education approach combined with the Concept Map Strategy impacts students' problem-solving skills. The influence of the realistic mathematics education approach with the Concept Map Strategy on students' problemsolving abilities was $41.6 \%$.

In addition, learning should be oriented towards mastering student competencies that have an impact on achieving maximum learning outcomes. This is in line with the view [19], which states that the competence of students must be possessed during the process and after learning is cognitive abilities (understanding, reasoning, application, analysis, observation, identification, investigation, exploration, connection, communication, inquiry, hypothesis, conjecture, generalization, creativity, problem-solving), affective abilities (self-control which includes self-awareness, emotional management, impulse control, positive activity motivation, empathy), and psychomotor abilities (socialization and personality which includes the ability to 
argue, present, behavior). In contemporary psychology terms, competencies/skills related to professional abilities (academic, especially cognitive) are called hard skills, which contribute to individual success up to $40 \%$.

Meanwhile, other competencies related to affective and psychomotor skills related to personality, socialization, and self-control are soft skills, contributing $60 \%$ to individual success. Suherman's view above is in line with [20] that the development of mathematical competencies is directed at improving life skills, especially in constructing reasoning, communication, and problem-solving. In addition, the development of mathematical competencies also emphasizes proficiency or skills in using technological devices to perform technical calculations (computation) and presentation in the form of images and graphics (visualization), which are important to support other skills that are cross-disciplinary skills and skills that are non-cognitive and development of values, norms, and ethics (soft skills).

Thus, it is very urgent to apply a problem learning model in mathematics learning in elementary schools that guide the higher-order thinking skills of elementary school students. In this case, students can apply knowledge and problem-solving skills to be helpful in everyday life. According to Polya, the solution to problem-solving contains four steps, namely understanding the problem, planning a solution, solving the problem as planned, and checking all the steps taken [21].

From some of the findings of previous relevant research, the RME approach is effective in the learning process of mathematics, which is also able to improve problem-solving skills. Therefore, the focus of this study is to determine the effect of implementing RME principles that can support problem-solving ability be HOST oriented at elementary

\section{Methodology}

This research is experimental research with a pretest-posttest control group design. The experimental group followed mathematics learning with the RME Principles while the control group took mathematics learning using the conventional learning model. The research sample was 41 students of class V SDK Wae Mata, Lembor District, West Manggarai Regency. The VA class had 20 students, while the VB class had a total of 21 students. It was using the random sampling technique, class VA as the experimental group meanwhile class VB as the control group. Initial treatment, the sample's problem-solving ability was assessed using HOTS questions. After treatment, the sample's problem-solving ability was assessed again at posttest. Students solve problems both individually and in groups using student worksheets on the fraction count operation material that measures HOTS-oriented non-routine questions during the treatment.

Based on the type of data, the data in this study were collected using the test method. The form of the test used was an essay test, a test item that measures problem solving ability to be HOTS-oriented. The test questions totaled 5 items with a variability coefficient of 0.83 in the very high category. The test instrument used has been checked for the validity and reliability of the items. The number of problem-solving skill-oriented test questions was five items in the description.

The data analysis used in this study used the t-test, which was preceded by the assumption test, namely the data distribution normality test and the data group variance homogeneity test. The prerequisite analysis used in this study included the normality test and the homogeneity test. The normality test aims to determine whether the data distribution is normally distributed 
or not. The normality test used the Kolmogorov-Smirnov statistical test with the help of the SPSS for the windows 23 program. The results obtained were compared with a significance value of 0.05 . The decision-making for the normality test is if the significance value (asym. Sig) $>0.05$, then the data is normally distributed and if the significance value (asym. Sig) $<0.05$, then the data is not normally distributed.

Meanwhile, the homogeneity test is used to determine whether the data comes from the same variant or not. Homogeneity test using Levene's statistic formula. As for knowing the variants of the experimental and control groups carried out using the SPPS for the windows 23 program. Decision-making is based on the significance value obtained, namely if the significance $>0.05$, then the variance is the same and vice versa if the significance value $<0.05$, the variant is different.

\section{Result and Discussion}

\subsection{Result}

A pretest precedes this experimental research for both groups, the experimental and control groups. Based on the pretest data processing score, it can be concluded that the two groups have an almost equal average problem-solving ability to be HOST-oriented. Details can be seen in Table 1 below.

Table 1. Pretest score data of problem-solving ability

\begin{tabular}{lcccccc}
\hline \multicolumn{1}{c}{ Group } & N & Mean & Median & SD & Variance & Range \\
\hline Experiment & 21 & 64.51 & 65 & 7.31 & 53.51 & 25 \\
Control & 20 & 63.75 & 65 & 5.74 & 33.01 & 25 \\
\hline
\end{tabular}

Based on the data in Table 1, it can be said that the initial conditions of the experimental class and control class based on the class average are not significantly different. Furthermore, the analysis of the normality test and the variance homogeneity of the data group was carried out. Based on the results of data normality testing, it was obtained $0.089>0.05$. Thus, the pretest data for students' creative thinking skills were normally distributed. The homogeneity test of the variant data groups found that Sig. 0, $161>0.05$, thus it can be said that the two groups have homogeneous variants. After the treatment was given, the two groups were given a posttest regarding their HOTS-oriented problem-solving skills. Table 2 represents the results of the data centering score calculation for problem-solving ability.

Table 2. Posttest score data of problem-solving ability

\begin{tabular}{lcccccc}
\hline \multicolumn{1}{c}{ Group } & N & Mean & Median & SD & Variance & Range \\
\hline Experiment & 21 & 81.71 & 80 & 6.58 & 43.26 & 25 \\
Control & 20 & 75.87 & 75 & 6.39 & 40.88 & 20 \\
\hline
\end{tabular}

Based on the data in Table 2, the mean score of the experimental group, that is, the class taught by using the RME approach, was higher than the mean score of the control group using the conventional approach. Furthermore, analysis of normality of data distribution and homogeneity test of group variance was carried out. Based on the test results, the Kolmogorov Smirnov significance figure is $0.180>0.05$, so it can be said that the data group problem-solving ability score comes from a normally distributed population and for testing the homogeneity of 
the variants of the data group obtained $0.091>0.05$, it can be said that the data posttest control class and experimental class come from homogeneous variants. It is furthermore testing the hypothesis using the independent t-test. Based on the analysis results obtained Sig $<0.05$, namely $0.001<0.05$, indicating that the RME approach is more effective in improving problemsolving ability be HOTS-oriented than conventional approaches.

After the treatment, it was found a significant effect. The results are shown in Table 3, with the posttest mean in the experimental class of 81.71 , while the posttest means in the control class is 75.87. This result demonstrates that there is a difference in the score before and after treatment. Additionally, Table 3 shows the average N-Gain from the pretest and posttest data.

Table 3. N-Gain Recapitulation

\begin{tabular}{ccccccc}
\hline Group & N & $\begin{array}{c}\text { Ideal } \\
\text { Score }\end{array}$ & $\begin{array}{c}\text { Maximum } \\
\text { Score }\end{array}$ & $\begin{array}{c}\text { Minimum } \\
\text { Score }\end{array}$ & $\begin{array}{c}\text { N-Gain } \\
\text { Average }\end{array}$ & $\begin{array}{c}\text { N-Gain } \\
\text { Category }\end{array}$ \\
\hline Experiment & 21 & 100 & 0.70 & 0.22 & 0.49 & Medium \\
Control & 20 & 100 & 0.50 & 0.13 & 0.34 & Medium \\
\hline
\end{tabular}

According to the data in Table 3, the experimental class's N-Gain is higher than the control class'. Figure 1 compares the N-Gain data for the experimental and control groups

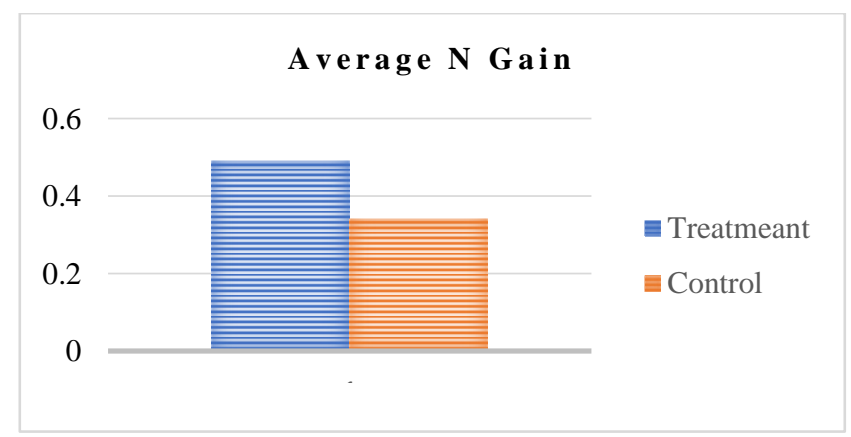

Fig 1. N-Gain Mean Diagram

The research findings show that the use of the RME approach is more effective than the conventional model in improving the problem-solving skills of grade $\mathrm{V}$ elementary school students. This is indicated by the value of tob $=38.071>\mathrm{tcv}=2.021$ with a significance of $0.001<0.05)$. Thus, classes taught using the RME approach are higher than those taught using the conventional approach. In other words, the application of the RME approach can improve problem-solving ability be HOTS-oriented in fraction material in the grade V of elementary schools.

\subsection{Discussion}

Based on the research findings, it was found that the value of tob $=38.071>\mathrm{tcv}=2.021$ with a significance of $0.001<0.05$. This shows that classes taught using the RME approach are higher than those taught using the conventional approach. In other words, the application of the RME approach can improve HOTS-oriented problem-solving skills in the fraction material at grade $\mathrm{V}$ of elementary schools. The findings of this study are supported by the results of research conducted by [16], [17], showing that RME learning influences improving students' problemsolving skills. [10]), which show that the use of Teffinger's creative learning model using RME 
principles can improve the creative thinking skills of grade $\mathrm{V}$ of elementary school students with co-variable numerical abilities.

This is supported by activities in learning where the RME principles guide the implementation of the process that leads to problem-solving ability be HOTS-oriented. In realistic problem recognition exercises, the RME principle is combined with the reality principle, which is demonstrated by introducing realistic problems that students may visualize. In resolving these issues, the teacher will employ the concept of operation, in which each person is immediately involved in solving problems by producing numerous ideas [9].

Additionally, as manifested in group discussion practices, the principle of interaction is also the principle of reality, as manifested in group discussions of realistic problems using the principle of activity. The principles of interaction, reality, and activity are expressed in students who solve problems using Polya's four steps, namely understanding the problem, planning how to solve it, carrying out the problem solving, and checking the answers obtained [21]. By grouping discussion groups of 4-5 students based on their skills, it is shown that students are actively involved in group discussions to solve problems using the interaction theory. The skill variation is used to divide students into classes to interact and communicate creatively about their ideas or approaches to solving mathematical problems.

Similarly, [22] demonstrates that learning with an effective learning model, in this case, the creative problem solving (CPS) learning model, will develop students' mathematical creative thinking skills. With the ability and understanding of good concepts to reduce the mistakes of students in solving problems or in solving math problems that are categorized as complex [23].

Moreover, group work allows students to engage with one another and share their thoughts or solutions to problems while respecting differences in perspectives, allowing less skilled students to receive assistance from more capable students. This is in line with Vygotsky's ZPD concept, which says that ZPD is a zone where students cannot complete complex tasks to be mastered independently but can be mastered with guidance and assistance from adults or more skilled students [24].

In this case, ZPD is the distance between the actual level of development shown in the ability to solve problems independently and the level of potential developmental abilities shown in the ability to solve problems with the help of adults or cooperate with more capable peers [25]. In this case, Vygotsky's theory is implemented by providing students with training both individually and in small groups to allow them to master the material without the assistance of a teacher. This also helps students improve their social experiences, as they would be prompted to ask about topics they do not understand [26].

Similarly, through teacher guidance, students can create questions and solve problems independently and in groups, as well as the concept of intertwined knowledge by linking prior knowledge, especially to solve fractional problems, and the tiered principle, which allows students to gradually solve realistic problems through an informal problem-solving process towards formal problem-solving. In this case, a problem developed by students can be solved in a variety of ways, including by folding paper, drawing images, using patterns, or equating the denominator while adding and subtracting fractions and being able to apply acceptable problemsolving procedures. When they are successfully completed informally, students can move to the formal level; for example, in this case, students can define fractions with different denominators symbolically.

This stage of learning can assist students in not only performing demonstrations but also in retaining information that is relevant and can be retained in long-term memory. Thus, the RME approach is capable of enhancing students' critical thinking skills. This is validated by research results from [27]), which indicate that by implementing the RME approach, students' critical 
thinking skills can be improved, and teachers' implementation of learning is categorized as very good.

This result is consistent with Jerome Bruner's learning theory, which states that in order for students to improve their intellectual abilities in learning a mathematical concept, the subject matter must be presented in a way that reflects their stages of cognitive growth/knowledge, allowing knowledge to be internalized into the person's cognitive structure. Bruner's opinion supports Jean Piaget's theory which states that the human thought process is a gradual development from concrete to abstract intellectual thinking [28].

In this case, students of elementary school age (7-12) years are in the concrete operational phase, and knowledge is presented from the concrete stage to the abstract stage. This refers to Jean Piaget's view that it is important to consider students' cognitive development when constructing logical-mathematical knowledge [29].

\section{Conclusion}

Based on the results of the study and discussion, the findings of this study indicate that the group taught using the RME approach was higher than the group taught using the conventional approach. tob $=38.071>\mathrm{tcv}=2.021$ with a significance of $0.001<0.05$ ). Thus, it can be said that classes taught using the RME approach are higher than those taught using the conventional approach. This shows that the application of the RME approach can improve problem-solving ability be HOTS-oriented in fraction material in grade V of elementary schools. Therefore, it is suggested that elementary school teachers train more students to solve non-routine questions that lead to HOTS.

\section{References}

[1] Partnership for 21st Century Skills, 21st Century Skills Map. Washington, DC: Partnership for 21 st Century Skills, 2011.

[2] B. Trilling and C. Fadel, 21st-century skills. Jossey-Bass, 2009.

[3] W. Setiawati, A. Oktavia, Y. Ariyana, R. Bestary, and A. Pudjiastuti, Buku Penilaian Berorientasi Higher Order Thinking Skills. Jakarta: Dirjen Guru dan Tenaga Pendidikan Kemendikbud, 2019.

[4] S. Ndiung and M. Jediut, "Pengembangan instrumen tes hasil belajar matematika peserta didik sekolah dasar berorientasi pada berpikir tingkat tinggi," Prem. Educ. J. Pendidik. Dasar dan Pembelajaran, vol. 10, no. 1, pp. 94-111, 2020.

[5] A. Schleicher, "PISA 2018: Insight and Interpretations," @OOECD 2019, 2019.

[6] Z. Arifin and H. Retnawati, "Pengembangan Instrumen Pengukur Higher Order Thinking Skills Matematika Siswa SMA Kelas X Developing an Instrument to Measure Mathematics Higher Order Thinking Skills of 10 th Grade Students in Senior High School," PYTHAGORAS J. Pendidik. Mat., vol. 12, no. 1, pp. 98-108, 2017.

[7] S. Fatimah, G. Muhsetyo, and S. Rahardjo, "No Title Proses Berpikir Tingkat Tinggi Siswa SMP dalam Menyelesaikan Soal Pisa dan Scaffoldingnya," J. Kaji. Pembelajaran Mat., vol. 3, no. 1, pp. 24-33, 2019.

[8] S. Y. Karaca and A. Özkaya, "The Effects of Realistic Mathematics Education on Students , Math Self Reports in Fifth Grades," Int. J. Curric. Instr., vol. 9, no. 1, pp. 81-103, 2017.

[9] M. Van Den Heuvel-panhuizen and P. Drijvers, "Realistic Mathematics Education," Encycl. Math. Educ., pp. 521-534, 2014.

[10] S. Ndiung, N. Dantes, I. Ardana, and A. Marhaeni, "Treffinger Creative Learning Model with RME Principles on Creative Thinking Skill by Considering Numerical Ability," Int. J. 
Insruction, vol. 12, no. 3, pp. 731-744, 2019.

[11] V. Arsaythamby and C. M. Zubainur, "How A Realistic Mathematics Educational Approach Affect Students 'Activities In Primary Schools ?," Procedia - Soc. Behav. Sci., vol. 159, pp. 309-313, 2014

[12] S. S. Alfuhaigi, "School Environment and Creativity Development : a Review of Literature," $J$. Educ. Instr. Stud. World, vol. 5, no. 2, pp. 33-38, 2015.

[13] E. Zakaria and M. Syamaun, "The Effect of Realistic Mathematics Education Approach on Students' The Effect of Realistic Mathematics Education Approach on Students 'Achievement And Attitudes Towards Mathematics," Math. Educ. Trends Res., vol. 1, pp. 32-40, 2017.

[14] C. K. Ekowati, M. Ardi, M. Darwis, H. M. D. Pua, S. Tahmir, and G. D. Dirawan, "The Application of Realistic Mathematics Education Approach In Teaching Mathematics In Penfui Kupang,” Int. J. Educ. Inf. Stud., vol. 5, no. 1, pp. 35-43, 2015.

[15] L. Catrining and I. W. Widana, "Pengaruh Pendekatan Pembelajaran Realistic Mathematics Education (RME) terhadap Minat dan Hasil Belajar Matematika," Emasains, vol. VII, no. 2, pp. $120-129,2018$

[16] A. Mulyati, "Pengaruh Pendekatan RME terhadap Kemampuan Pemecahan Masalah Siswa pada Materi Operasi Hitung Campuran di Kelas IV SD IT Adzkia I Padang," J. Didakt. Mat., vol. 4, no. 1, pp. 90-97, 2017.

[17] K. S. Asih, "Keefektifan Model Pembelajaran Realistic Mathematics Education (RME) Terhadap Kemampuan Pemecahan Masalah Matematika," Think. Ski. Creat. J., vol. 2, no. 2, pp. 103-110, 2019.

[18] S. M. Sari, "Pengaruh Pendekatan Realistic Mathematics Education (RME) Dengan Strategi Peta Konsep Terhadap Kemampuan Pemecahan Masalah Matematika Mahasiswa PGMI IAIN Bengkulu," J. Pendidik. Mat. Raflesia, vol. 4, no. 1, pp. 53-59, 2019.

[19] E. Suherman, "Model Belajar dan Pembelajaran Berorientasi Kompetensi Siswa," Educ. J. Pendidik. dan Budaya, vol. 5, no. 2, pp. 1-31, 2008.

[20] Permendikbud, "Permendikbud," in Permendikbud Nomor 21 Tahun 2016 Tentang Standar Isi Pendidikan Dasar dan Menengah, 2016, pp. 1-234.

[21] Nurfatanah, Rusmono, and Nurjannah, "Kemampuan pemecahan masalah matematika siswa sekolah dasar," Pros. Semin. dan Disk. Nas. Pendidik. Dasar, pp. 546-551, 2018.

[22] A. Septian, E. Komala, and K. A. Komara, "Pembelajaran dengan Model Creative Problem Solving untuk Meningkatkan Kemampuan Berpikir Kreatif Matematis Siswa," Prisma, vol. 8, no. 2, pp. 182-190, 2019.

[23] E. Sennen, S. Ndiung, and K. Supardi, "Analisis Kesalahan Siswa Sekolah Dasar dalam Menyelesaikan Soal-Soal Matematika yang Terkategori Sulit pada UASBN," J. Pendidik. dan Kebud. Missio, vol. 8, no. 2, pp. 253-268, 2016.

[24] D. Christmas, C. Kudzai, and M. Josiah, "Vygotsky' s Zone of Proximal Development Theory: What are its Implications for Mathematical Teaching? By," Greener J. Soc. Sci., vol. 3, no. 7, pp. 371-377, 2013.

[25] S. Siyepu, "The zone of proximal development in the learning of mathematics," South African J. Educ., vol. 33, no. 2, pp. 1-13, 2013.

[26] S. Rohaendi and N. I. Laelasari, "Penerapan Teori Piaget dan Vygotsky Ruang Lingkup Bilangan dan Aljabar pada Siswa Mts Plus Karangwangi," vol. 9, no. 1, pp. 65-76, 2020.

[27] A. Kurnia, E. B. Irawan, and C. Sa'dijah, "Penerapan Realistic Mathematics Education untuk Meningkatkan Kemampuan Berpikir Kritis Siswa Kelas V," J. Pendidik. Teor. Penelitian, dan Pengemb., vol. 2, no. 4, pp. 524-530, 2017.

[28] I. M. Ardana, I. P. W. Ariawan, and D. G. H. Divayana, "Measuring the effectiveness of blcs model (bruner, local culture, scaffolding) in mathematics teaching by using expert system-based cse-ucla," Int. J. Educ. Manag. Eng., vol. 7, no. 4, pp. 1-12, 2017.

[29] N. R. Nool, "Effectiveness of an Improvised Abacus in Teaching Addition of Integers," vol. 30, pp. 307-311, 2012. 